Eur J Clin Chem Clin Biochem

1995; 33:127-133

(c) 1995 Walter de Gruyter \& Co.

Berlin · New York

\title{
Urinary Selenium Status of Healthy People
}

\author{
By Elena María Rodríguez Rodriguez, Maria Teresa Sanz Alaejos and Carlos Diaz Romero \\ Department of Analytical Chemistry, Food Science \& Toxicology, University of La Laguna, La Laguna, Spain
}

(Received September 16, 1994/January 2, 1995)

\begin{abstract}
Summary: Urinary selenium (Se) concentrations ( $\mu \mathrm{g} / 1$ of urine and $\mu \mathrm{g} / \mathrm{g}$ of creatinine) and urinary Se excretions ( $\mu \mathrm{g} / \mathrm{d}$ and $\mu \mathrm{g} / \mathrm{d} \cdot \mathrm{kg}$ of body weight) have been determined in healthy Canarian people. Urinary Se status was relatively low and similar to those data published from European regions. Females excreted daily significantly $(\mathrm{P}=0.005)$ higher amounts of Se per $\mathrm{kg}$ of body weight in urine than males. An increase of daily urinary Se excretion was observed up to 30 years of age. Children $(<10$ years old) had daily urinary Se excretion per $\mathrm{kg}$ of body weight higher than persons with age $>10$ years old. Both units of Se excretion, $\mu \mathrm{g} / \mathrm{d}$ and $\mu \mathrm{g} / \mathrm{d} \cdot \mathrm{kg}$, increased or decreased respectively with weight and height of the individuals. Food habits such as consumption of rich protein or rich fibre food, and drinking alcohol or coffee as well as smoking do not seem to influence the urinary Se status. Depletion of daily urinary Se excretion was observed with the increase of physical exercise. Unit of concentration $(\mu \mathrm{g} / \mathrm{g}$ of creatinine) is a more adequate indicator of the urinary Se excretion than the unit $\mu \mathrm{g} / \mathrm{l}$.
\end{abstract}

\section{Introduction}

Past decade, selenium (Se) has been the focus of a lot of research work because its beneficial effects occurs in a narrow range of concentration, below which it can not perform its essential function and above which its effects are toxic. Selenium is an essential trace element that participates in processes of detoxification because it forms a part of glutathione peroxidase (1). A second important enzymatic function of Se has recently been found. Selenium plays a role on the thyroid hormone and iodide metabolism because its deficiency inhibits the activity of the type I iodothyronine deiodinase $(2-5)$. Thus, there is an increasing interest for assessing Se status in humans, one of them is the establishment of Se levels in human fluids, such as urine. A strong correlation has been found between dietary $\mathrm{Se}$ and daily urinary excretion in a wide range of populations from all over the world with very different dietary intake (6). Therefore that great variation in urinary Se status in healthy people is mainly a consequence of the variability in Se intake and body burden (6). Age, sex, and living environment influence the concentrations of certain trace elements in urine. Also, even habits such as smok- ing tobacco and consuming alcohol could be considered (7), because they can affect the metabolism of some of the trace elements.

The purpose of this study has been to find out the urinary Se concentration (expressed in $\mu \mathrm{g} / \mathrm{l}$ of urine and $\mu \mathrm{g} / \mathrm{g}$ of creatinine), and excretion (expressed in $\mu \mathrm{g} / \mathrm{d}$ and $\mu \mathrm{g} / \mathrm{d} \cdot \mathrm{kg}$ of body weight) in healthy Canarian people. Also, the influence of sex, age, weight and height, and several other habits on the urinary Se status have been evaluated.

\section{Materials and Methods}

Apparatus

Fluorescence Spectrophotometer Perkin-Elmer model MFP-44A with automatic recorder, arc of xenon Osram XBO, differential corrected spectra unit DCSU-1, digital lector VDR-3, and heating water bath Selecta Frigitherm S-382.

\section{Reagents and solutions}

- Selenium standard solution $(1000 \mu \mathrm{g} / \mathrm{l})$ Fisher. Working standards $(0-250 \mu \mathrm{g} / \mathrm{l})$ were prepared for dilution of the latter solution with milli-Q water. 
- 2,3-Diaminonaphthalene solution-(6.85 mmol/l). The 2,3-diaminonaphthalene was previously crystallized and the solution was purified and stored according to a previous paper (8).

- Disodium ethylenediaminetetraacetic acid $\left(\mathrm{Na}_{2} \mathrm{EDTA} \cdot 2 \mathrm{H}_{2} \mathrm{O}\right)$ solution $(0.04 \mathrm{~mol} / \mathrm{l})$.

- Nitric, perchloric, sulphuric, hydrochloric acids, cyclohexane and other reagents used were of analytical quality.

\section{Samples}

24-h urine was collected by discarding the first urine in the morning and collecting urine $24-\mathrm{h}$ including the first urine of the next morning. The specimens were taken from 80 healthy volunteers (41 males +39 females) of the population of the province of Santa Cruz of Tenerife (Canary Islands, Spain). After, total volume of 24-h urine and $\mathrm{pH}$ were measured and then the samples were stored frozen $\left(-20^{\circ} \mathrm{C}\right)$ in containers of polyethylene without conservants. If sedimentation occurred, a suspension was produced by vigorous shaking, before taking the aliquot for analysis.

Data about age ( $30.5 \pm 15.4 ; 3-74$ years), height (164 \pm 16 ; 96$195 \mathrm{~cm})$ and body weight $(62.7 \pm 17.8 ; 17-106 \mathrm{~kg})$ were recorded. Also information about practice of physical exercise, smoking and some eating habits such as consumption of rich protein or fibre food, consumption of alcohol and coffee was considered in order to discover their effects on the urinary Se excretion.

\section{Procedures of determination}

Creatinine levels were determined by the Jaffé's method (9).

Selenium determination has been carried out fluorimetrically by the Watkinson' method (10), using 2,3-diaminonaphthalene as the complexing reagent.

In a previous paper (8), this method was studied and optimized. The optimized method was assayed on healthy and spiked urinary samples, obtaining a very good recovery $(99.6 \pm 3.1 \%)$, which agrees with most authors. The within-day precision of the method applied on urine samples was $3.2 \%(11.9 \mu \mathrm{g} / \mathrm{l}, \mathrm{n}=5)$ or $2.7 \%$ $(27.3 \mu \mathrm{g} / \mathrm{l}, \mathrm{n}=5)$ and the between-day precision was $4.4 \%(24.8$ $\mu \mathrm{g} / \mathrm{l}, \mathrm{n}=6)$ or $3.9 \%(33.9 \mu \mathrm{g} / \mathrm{l}, \mathrm{n}=6)$. The linear interval was confirmed between $0-250 \mu \mathrm{g} / \mathrm{l}$, the optimum interval being between $10-50 \mu \mathrm{g} / \mathrm{l}$. The detection limit of this fluorimetric procedure (mean $\pm 3 \mathrm{SD}$ blank fluorescence value), was $0.82 \mu \mathrm{g} / 1$ (0.82 ng).

\section{Statistics}

Statistics were calculated with the SPSS/PC+ program. Analysis of variance was applied for all the studied variables in order to compare the mean values obtained among the different groups of the studied population. Mean values obtained in the studied different groups were compared using t-test, assuming that there are differences between mean values when statistical comparison gave $P<0.050$. All results have been confirmed by non-parametric statistics such as Kolmogorov-Smirnov test because low number of data $(<10)$ are present in several subgroups. Simple linear correlation analysis was used to obtain a measure of the strength of the relationship between two variables.

\section{Results and Discussion}

Urinary selenium (Se) was expressed in units of Se concentrations ( $\mu \mathrm{g} / \mathrm{l}$ of urine and $\mu \mathrm{g} / \mathrm{g}$ of creatinine), and Se excretion ( $\mu \mathrm{g} / \mathrm{d}$ and $\mu \mathrm{g} / \mathrm{d} \cdot \mathrm{kg}$ of body weight). Similarly, urinary creatinine was expressed in concentration $(\mathrm{mg} / \mathrm{l})$ and units of excretion ( $\mathrm{g} / \mathrm{d}$ and $\mathrm{g} / \mathrm{d} \cdot \mathrm{kg}$ body weight) (tab. 1). Also, data of $\mathrm{pH}$ and daily volume of urine are included in this table 1. Our data can be included in the typical range of urinary Se status of most regions of Europe or normal reference values. Thus, they were lower than those in seleniferous areas and higher than typical Se excretion of areas where Keshan disease occurs (6).

Certain authors have found no significant differences between sexes considering the units $\mathrm{Se}, \mu \mathrm{g} / \mathrm{l}$ of urine (11, $12)$ and $\mu \mathrm{g} / \mathrm{g}$ of creatinine $(13,14)$. However, other investigators found concentrations of Se for females (15, 16) significantly higher than for males, in spite of the fact that females obtained less dietary Se than males (16). Our data presented higher $(p=0.482)$ values of unit Se, $\mu \mathrm{g} / \mathrm{g}$ of creatinine for women. With respect to the units of excretion, males excreted daily higher $(P=0.121)$ amounts of $\mathrm{Se}$ in urine than females due possibly to their higher body weight. The difference in all cases were not significant $(P>0.100)$. However, if the unit of Se daily excretion for $\mathrm{kg}$ of body weight is compared between sexes, females excreted significantly $(\mathrm{P}=0.005)$ higher amounts of Se than males. Applying the Kolmogorov-Smirnov test, these differences were confirmed $(p=0.048)$. This fact seems to indicate that males tend to retain Se more efficiently than females, which has been suggested by other authors (16). The range and coefficient of variation of this unit of $\mathrm{Se}$ excretion for females were higher than for males. The $\mathrm{pH}$ and total daily volume of urine do not differ significantly between sexes.

The influence of age on the urinary Se concentrations in $\mu \mathrm{g} / \mathrm{l}$ and in $\mu \mathrm{g} / \mathrm{g}$ of creatinine is shown in figure 1 . The unit of urinary Se concentration $\mu \mathrm{g} / \mathrm{l}$ presented the maximum mean concentration in the interval of 11-20 years,

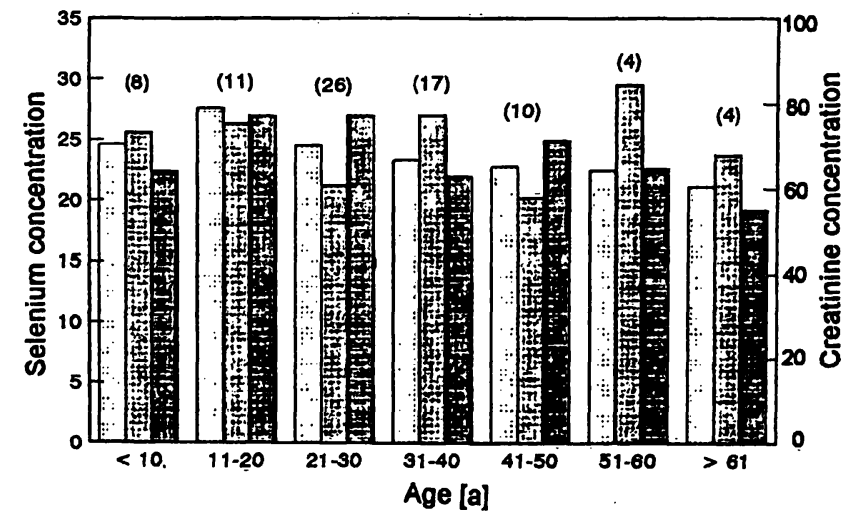

Fig. 1 Urinary Se concentrations ( $\mu \mathrm{g} / \mathrm{l}$ of urine and $\mu \mathrm{g} / \mathrm{g}$ of creatinine) and creatinine concentrations (mg/l) according to age of individuals.

Units: $\square \mathrm{Se}, \mu \mathrm{g} / \mathrm{l}$ of urine, $⿴ \mathrm{Se}, \mu \mathrm{g} / \mathrm{g}$.of creatinine, $\square$ creatinine, $\mathrm{mg} / \mathrm{l}$ 
Tab. 1 Main statistics of urinary Se and creatinine for males, females and overall of the individuals.

\begin{tabular}{lllll}
\hline Analyte & $\begin{array}{l}\text { Overall } \\
\left(n^{*}=80\right)\end{array}$ & $\begin{array}{l}\text { Female } \\
\left(n^{*}=39\right)\end{array}$ & $\begin{array}{l}\text { Male } \\
\left(n^{*}=41\right)\end{array}$ & $\begin{array}{l}\text { Signi- } \\
\text { ficance } \\
(P)\end{array}$
\end{tabular}

1) Selenium

$(\mu \mathrm{g} / \mathrm{l})$

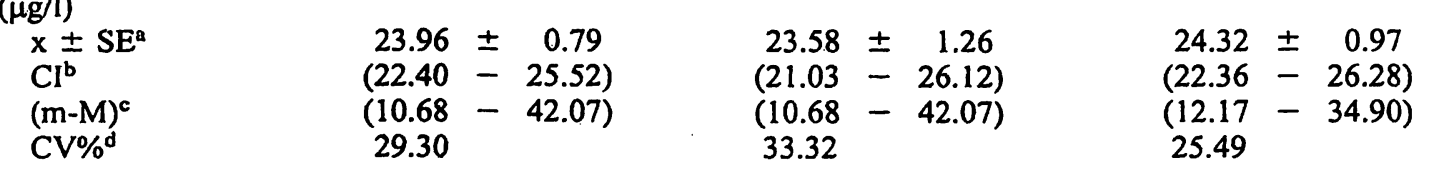

$(\mu \mathrm{g} / \mathrm{d})$

$x \pm S E$

CI

(m-M)

$\mathrm{CV} \%$
$25.43 \pm 0.94$
$(23.55-27.32)$
$(11.39-48.63)$
33.30

$23.92 \pm 1.22$

$(21.44 \div 26.40)$

$(11.66-42.53)$

31.95

$26.87 \pm 1.41$
$(24.01-29.72)$
$(11.39-48.63)$
33.68

0.223

0.638

( $\mu \mathrm{g} / \mathrm{g}$ of creatinine)

$\begin{array}{lr}\mathrm{X} \pm \mathrm{SE} & 23.87 \pm 1.27 \\ \mathrm{CI} & (21.35-26.40) \\ (\mathrm{m}-\mathrm{M}) & (12.17-68.81) \\ \mathrm{CV} \% & 47.52\end{array}$

$24.80 \pm 2.05$
$(20.66 \pm 28.94)$
$(12.35-68.81)$
51.49

$23.00 \pm 1.54$

$(19.88-26.12)$

$(12.17-59.46)$

42.96

(P)

$(\mu \mathrm{g} / \mathrm{d} \cdot \mathrm{kg})$
$\mathrm{X} \pm \mathrm{SE}$

$\mathrm{CI} \pm \mathrm{SE}$

$0.427 \pm 0.017$

$(0.393-0.461)$

(m-M)

$(0.178-0.980)$

36.07
$0.476 \pm \quad 0.027$
$(0.421-0.531)$
$(0.276-0.990)$ 35.50
$0.380 \pm \quad 0.019$
$(0.342-0.419)$
$(0.178-0.749)$
32.11

8.509

0.005

2) Creatinine

(mg/l)

$\begin{array}{lc}\mathrm{x} \pm \mathrm{SE} & 1120.2 \pm 45.0 \\ \mathrm{CI} & (1030.7-1209.7) \\ (\mathrm{m}-\mathrm{M}) & (255.6-2066.7) \\ \mathrm{CV} \% & 35.89\end{array}$

(g/d)

$\begin{array}{lr}\mathrm{x} \pm \mathrm{SE} & 1.16 \pm 0.04 \\ \mathrm{CI} & (1.08-1.24) \\ (\mathrm{m}-\mathrm{M}) & (0.32-1.93) \\ \mathrm{CV} \% & 31.67\end{array}$

$1062.2 \pm 61.0$
$(938.6-1185.7)$
$(428.6-2066.7)$
35.88

$1175.4 \pm 65.3$

$(1043.4=1307.4)$

$(255.6-2041.7)$

36.83

0.500

0.482

2.45

0.121

$1.23 \pm 0.06$
$(1.13-1.34)$
$(0.65-1.91)$
28.78

2.935

0.091

$1.09 \pm 0.06$
$(0.97-1.21)$
$(0.32-1.93)$
34.22

1.597

0.210

$(\mathrm{mg} / \mathrm{d} \cdot \mathrm{kg})$

$\mathrm{x} \pm \mathrm{SE}$

CI

$19.45 \pm 0.73$

$(18.01-20.92)$

$21.51 \pm 1.21$

$(19.07-23.96)$

$17.52 \pm 0.74$

$(16.01-19.02)$

$(9.13-27.10)$

$\mathrm{CV} \%$

33.64

35.05

27.18

$\begin{array}{lr}\text { 3) Volume } & \\ \text { (1) } & \\ \mathrm{x} \pm \mathrm{SE} & 1.14 \pm 0.05 \\ \mathrm{CI} & (1.03-1.25) \\ (\mathrm{m}-\mathrm{M}) & (0.37-3.20) \\ \mathrm{CV} \% & 42.99\end{array}$

* $\mathrm{n}=$ number of subjects.

a $\overline{\mathrm{x}} \pm \mathrm{SE}=$ Mean \pm Standard Error.

b $\mathrm{CI}=95 \%$ Confidence Interval $=\overline{\mathrm{x}} \pm \mathrm{SE} \cdot \mathrm{t}\left(\mathrm{P}=0.05, \mathrm{n}^{*}\right)$.

detecting a progressive decrease, although not significant $(P=0.166)$, with the age of the individuals (fig. 1). Bratakos et al. (16) in a study carried out on morning urine of normal Greek people observed an increase with age to 40-50 years and afterwards a decrease with age, which do not exactly agree with was found here. In con- trast, other authors (17) have reported that urinary Se concentrations do not change with age. Elderly people ( $>60$ years) had lower $(P=0.019)$ urinary Se concentrations $(\mathrm{Se}, \mu \mathrm{g} / \mathrm{l})$ than adults, which agrees with published data from Greece (16) or from Belgium (18). This could be due to the lower Se intake and/or increased 
diuresis (16). However, these ${ }^{-d i f f e r e n c e s ~ c o u l d ~ n o t ~ b e ~}$ deduced when non-parametric tests were used because the low number of data. No clear tendencies were found when the unit of Se concentration ( $\mu \mathrm{g} / \mathrm{g}$ of creatinine) was considered. Possibly the decrease of urinary creatinine concentration with age (fig. 1), compensates for the decrease of urinary Se concentration. However, Hasunuma et al. (15) have found higher Se/creatinine values in 0-9 years of age for both sexes, which attributed to the lower urinary creatinine concentration in these age groups. Variables of urinary Se related to excretion best reflect the differences among the several groups of population considered as a function of age (fig. 2). Urinary Se excretions ( $\mu \mathrm{g} / \mathrm{d}$ and $\mu \mathrm{g} / \mathrm{d} \cdot \mathrm{kg}$ body weight) change significantly $(P=0.010$ and $P=0.005$, respectively) with the age of the individuals. Considering the unit Se, $\mu \mathrm{g} / \mathrm{d}$, a progressive increase was observed to 30 years of age, finding similar results with the total volume of urine (fig. 2). Children ( $<10$ years old) presented significantly $(P=0.008)$ lower daily $\mathrm{Se}$ excretion and higher $(P=0.000)$ Se excretion per $\mathrm{kg}$ of body weight than persons with age $>10$ years old, which could be a consequence of the fast growth behaviour of children. These results were confirmed applying the KolmogorovSmirnov test, obtaining $\mathrm{P}=0.004$ and $\mathrm{P}=0.007$ for Se excretion and $\mathrm{Se}$ excretion per $\mathrm{kg}$ of body weight respectively.

Both units of urinary Se concentrations did not change significantly with the intervals of weight and height considered. However, the units of urinary Se excretion, $\mu \mathrm{g} / \mathrm{d}$ or $\mu \mathrm{g} / \mathrm{d} \cdot \mathrm{kg}$ of body weight, significantly $(\mathrm{P}<0.040)$ increased or decreased respectively with the weight and height of individuals (fig. 3). Appling the Tukey's multiple comparison, people with $<30 \mathrm{~kg}$ resulted to have higher significantly $(P<0.050)$ urinary Se excre-

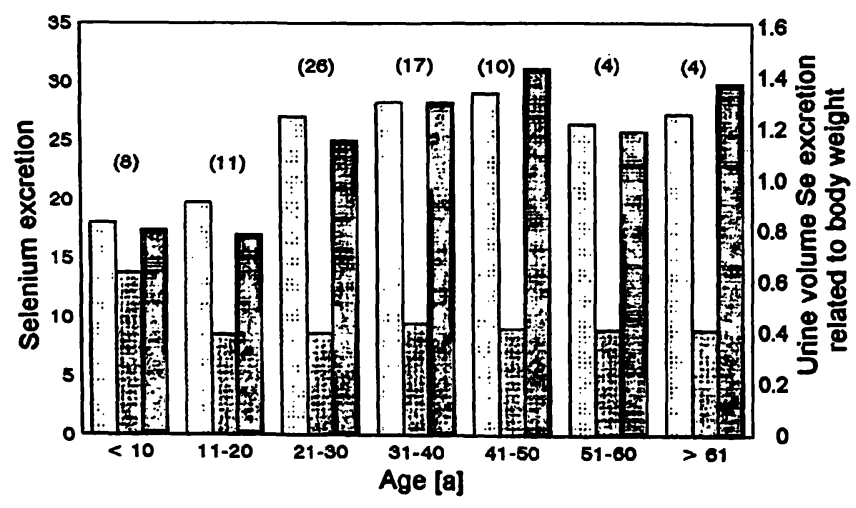

Fig. 2 Urinary Se excretions ( $\mu \mathrm{g} / \mathrm{d}$ and $\mu \mathrm{g} / \mathrm{d} \cdot \mathrm{kg}$ ) and volume excreted according to age of individuals, indicating the number of individuals of the corresponding interval in parentheses.

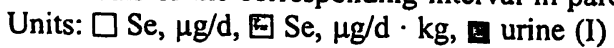
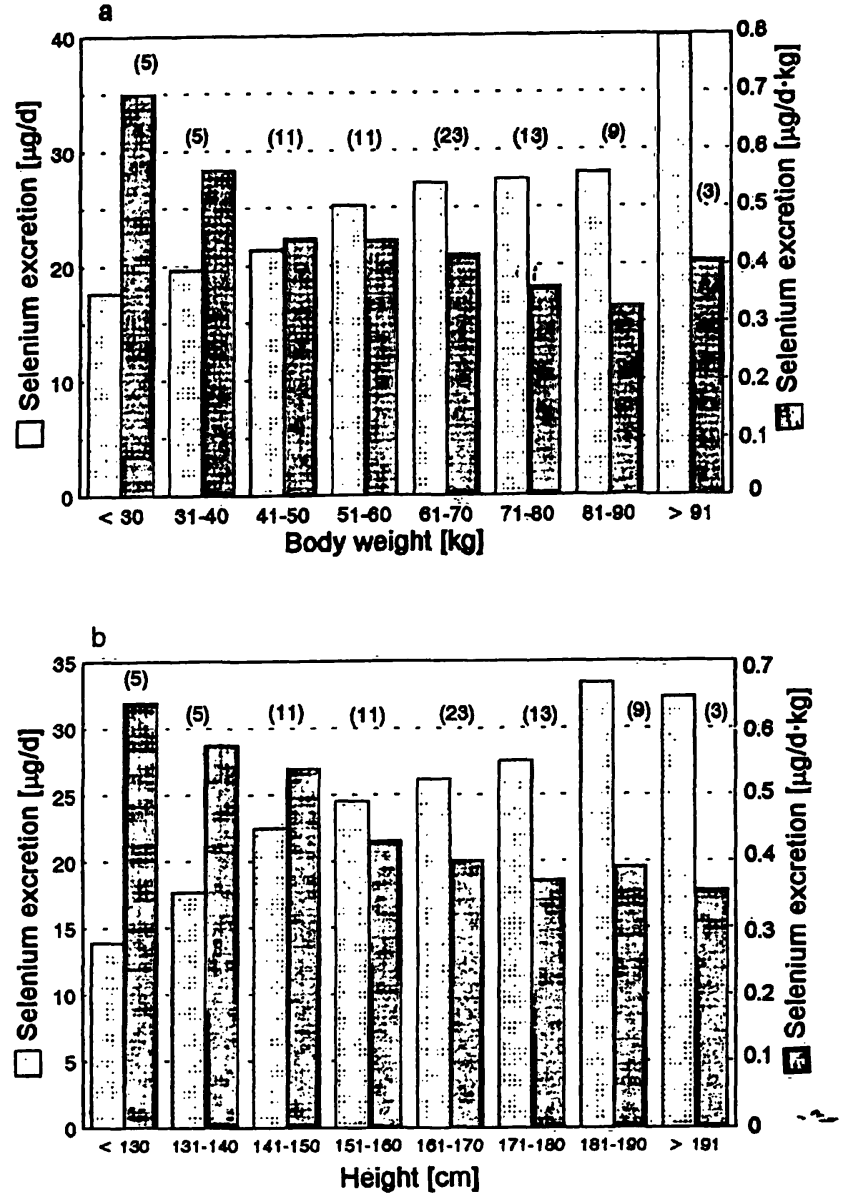

Fig. 3 Urinary Se excretions ( $\mu \mathrm{g} / \mathrm{d}$ and $\mu \mathrm{g} / \mathrm{d} \cdot \mathrm{kg}$ ) according to weight (a) and height (b) of individuals, indicating the number of individuals of the corresponding interval in parentheses.

tion $(\mu \mathrm{g} / \mathrm{d} \cdot \mathrm{kg})$ than the rest of the intervals of weight considered except the interval $30-40 \mathrm{~kg}$ of weight.

With respect to some eating habits manifested by the studied individuals, small differences of urinary $\mathrm{Se}$ status were observed (tab. 2). Individuals who consume rich protein food less than twice per week, presented lower urinary Se status than individuals who consume these products more than three times a week. This can be related to the fact that the most important sources of $\mathrm{Se}$ are rich protein foods $(11,19-20)$. Moreover, Palmer et al. (21) have found a very significant $(r=0.933, P<0.001)$ correlation between Se and protein intakes. So, when the Se intake increases due to high consumption of rich Se food, the urinary Se status must also be increased in order to maintain the Se balance in the organism. Persons who consume rich fibre food less than three times per week, had higher urinary Se status than the rest.

Significant Se depletion has been observed in urine (22) and in serum (22-26) of alcoholics. In this study, urinary Se concentrations and excretions of the occasional alcohol drinkers and the non alcohol drinkers were very similar $(P>0.300)$. But all the alcohol drinkers studied here had normal liver function. Thus, it can be deduced 
Tab. 2 Main statistics of urinary Se according to some habits manifested of the individuals.

\begin{tabular}{|c|c|c|c|c|c|}
\hline & \multirow[b]{2}{*}{$\mathrm{n}^{*}$} & \multicolumn{2}{|c|}{ Urinary Se concentration } & \multicolumn{2}{|c|}{ Urinary Se excretion } \\
\hline & & $\mu \mathrm{g} / 1$ & $\mu \mathrm{g} / \mathrm{g}$ of creatinine & $\mu g / d$ & $\mu \mathrm{g} / \mathrm{d} \cdot \mathrm{kg}$ \\
\hline \multicolumn{6}{|c|}{ Consumption rich protein food } \\
\hline Low & 9 & $\begin{array}{c}21.99 \pm 2.85^{a} \\
(15.41-28.57)^{b}\end{array}$ & $\begin{array}{c}23.01 \pm 3.97 \\
(13.85-32.17)\end{array}$ & $\begin{array}{c}24.61 \pm 3.84 \\
(15.76-33.47)\end{array}$ & $\begin{array}{c}0.476 \pm 0.037 \\
(0.290-0.462)\end{array}$ \\
\hline High & 68 & $\begin{array}{c}24.36 \pm 0.81 \\
(22.74-25.98)\end{array}$ & $\begin{array}{c}24.34 \pm 1.39 \\
(21.45-27.11)\end{array}$ & $\begin{array}{c}25.57 \pm 1.00 \\
(23.59-27.56)\end{array}$ & $\begin{array}{c}0.435 \pm 0.019 \\
(0.396-0.473)\end{array}$ \\
\hline \multicolumn{6}{|c|}{ Consumption rich fibre food } \\
\hline Low & 13 & $\begin{array}{c}24.85 \pm 1.44 \\
(21.71-27.99)\end{array}$ & $\begin{array}{c}27.54 \pm 4.61 \\
(17.50-37.58)\end{array}$ & $\begin{array}{c}25.73 \pm 2.48 \\
(20.33-21.13)\end{array}$ & $\begin{array}{c}0.432 \pm 0.037 \\
(0.352-0.512)\end{array}$ \\
\hline High & 66 & $\begin{array}{c}23.82 \pm 0.91 \\
(22.00-25.64)\end{array}$ & $\begin{array}{c}23.01 \pm 1.24 \\
(20.54-25.48)\end{array}$ & $\begin{array}{c}35.33 \pm 1.05 \\
(23.24-27.42)\end{array}$ & $\begin{array}{c}0.426 \pm 0.020 \\
(0.387-0.465)\end{array}$ \\
\hline \multicolumn{6}{|c|}{ Consumption of coffee $e^{c}$} \\
\hline No & 15 & $\begin{array}{c}23.97 \pm 1.55 \\
(20.65-27.28)\end{array}$ & $\begin{array}{c}21.09 \pm 1.62 \\
(17.61-24.58)\end{array}$ & $\begin{array}{c}26.48 \pm 2.34 \\
(21.47-31.50)\end{array}$ & $\begin{array}{c}0.413 \pm 0.042 \\
(0.323-0.502)\end{array}$ \\
\hline Yes & 51 & $\begin{array}{l}23.62 \pm 0.96 \\
(21.68-25.55)\end{array}$ & $\begin{array}{c}23.93 \pm 1.60 \\
(20.72-27.13)\end{array}$ & $\begin{array}{c}27.34 \pm 1.09 \\
(25.14-29.53)\end{array}$ & $\begin{array}{c}0.405 \pm 0.017 \\
(0.372-0.438)\end{array}$ \\
\hline \multicolumn{6}{|c|}{ Consumption of alcohol ${ }^{c}$} \\
\hline No & 28 & $\begin{array}{c}22.81 \pm 1.28 \\
(20.19-25.44)\end{array}$ & $\begin{array}{c}23.73 \pm 2.25 \\
(19.12-28.34)\end{array}$ & $\begin{array}{c}26.12 \pm 1.56 \\
(22.93-29.31)\end{array}$ & $\begin{array}{c}0.408 \pm 0.029 \\
(0.350-0.465)\end{array}$ \\
\hline Yes & 38 & $\begin{array}{c}24.35 \pm 1.06 \\
(22.19-26.50)\end{array}$ & $\begin{array}{c}22.95 \pm 1.54 \\
(19.83-26.07)\end{array}$ & $\begin{array}{c}27.90 \pm 1.29 \\
(25.29-30.50)\end{array}$ & $\begin{array}{c}0.401 \pm 0.019 \\
(0.363-0.438)\end{array}$ \\
\hline \multicolumn{6}{|c|}{ Consumption of tobacco ${ }^{c}$} \\
\hline No & 48 & $\begin{array}{c}24.28 \pm 0.98 \\
(22.32-26.24)\end{array}$ & $\begin{array}{c}22.74 \pm 1.38 \\
(19.97-25.52)\end{array}$ & $\begin{array}{c}26.87 \pm 1.01 \\
(24.84-28.91)\end{array}$ & $\begin{array}{c}0.400 \pm 0.015 \\
(0.369-0.431)\end{array}$ \\
\hline Yes & 18 & $\begin{array}{c}22.13 \pm 1.46 \\
(19.04-25.22)\end{array}$ & $\begin{array}{c}24.73 \pm 3.04 \\
(18.31-31.15)\end{array}$ & $\begin{array}{c}27.86 \pm 2.48 \\
(22.64-33.08)\end{array}$ & $\begin{array}{c}0.413 \pm 0.042 \\
(0.325 \pm 0.501)\end{array}$ \\
\hline \multicolumn{6}{|c|}{ Physical exercise } \\
\hline No & 15 & $\begin{array}{c}22.16 \pm 1.55 \\
(18.83-25.49)\end{array}$ & $\begin{array}{c}27.31 \pm 4.42 \\
(17.83-36.79)\end{array}$ & $\begin{array}{c}28.85 \pm 2.40 \\
(23.70-34.00)\end{array}$ & $\begin{array}{c}0.414 \pm 0.030 \\
(0.350-0.478)\end{array}$ \\
\hline Sometimes & 37 & $\begin{array}{c}23.55 \pm 1.13 \\
(21.26-25.84)\end{array}$ & $\begin{array}{c}22.84 \pm 1.33 \\
(20.15-25.54)\end{array}$ & $\begin{array}{c}26.33 \pm 1.39 \\
(23.52-29.15)\end{array}$ & $\begin{array}{c}0.426 \pm 0.024 \\
(0.378-0.474)\end{array}$ \\
\hline Usually & 28 & $\begin{array}{c}25.46 \pm 1.44 \\
(22.50-28.42)\end{array}$ & $\begin{array}{c}23.40 \pm 2.15 \\
(18.99-27.81)\end{array}$ & $\begin{array}{c}22.41 \pm 1.37 \\
(19.59-25.23)\end{array}$ & $\begin{array}{c}0.435 \pm 0.035 \\
(0.364-0.507)\end{array}$ \\
\hline
\end{tabular}

* $\mathrm{n}=$ number of subjects.

a $\bar{x} \pm \mathrm{SE}=$ Mean \pm Standard Error.

b $\quad C I=95 \%$ Confidence Interval $=\bar{x} \pm S E \cdot t\left(p=0.05, n^{*}\right)$.

c Data eliminated children with age less than 14 years.

that decrease in the urinary Se status in alcohol consumers must be produced concomitantly with the deterioration of the liver function. Consuming coffee does not seem to affect the urinary Se status. Only, mean concentration (Se, $\mu \mathrm{g} / \mathrm{g}$ of creatinine) obtained in coffee consumers were slightly higher $(p=0.362)$ than the concentrations found in non coffee drinking individuals. On the other hand, some authors $(27-28)$ have found mean Se concentrations in blood plasma of smokers of tobacco lower than those concentrations obtained in nonsmokers. However, our data of the urinary Se concentrations $(\mu \mathrm{g} / \mathrm{l})$ were slightly lower $(\mathrm{P}=0.254)$ in smokers. If the urinary Se concentrations are expressed in $\mu \mathrm{g} / \mathrm{g}$ of creatinine, a gradual increase of this unit is observed with the consumption of tobacco, although this increase is not significant $(P=0.496)$. No statistical difference
$(\mathrm{P}>0.600)$ in urinary Se excretion $(\mu \mathrm{g} / \mathrm{d}$ and $\mu \mathrm{g} / \mathrm{d} \cdot \mathrm{kg})$ was found between smokers and non-smokers, which has been observed by other authors $(11,14)$.

A small increase in the urinary Se concentration $(\mu \mathrm{g} / \mathrm{l})$ was observed with the increase of physical exercise (tab. 2 ), which could be a consequence of the losses of water through perspiration. Some authors (11) have found that Se concentration in urine was about twice as high after jogging than before jogging. They concluded that muscle work with an increased energy consumption produces an increased $\mathrm{Se}$ excretion in urine. The daily excretion of creatinine is clearly influenced by the muscle mass (29). This could explain that those authors (11), using the unit of urinary Se concentration $\mu \mathrm{g} / \mathrm{g}$ of creatinine, found no significant difference before or after 160 
$\mathrm{km}$ of jogging. In this study, the individuals who never do any physical exercise presented mean urinary Se concentration higher $(P=0.426)$ than those who usually or sometimes do exercise. On the other hand, a significant $(P=0.038)$ depletion has been observed in daily Se excretion with the increase of physical excercise of the individuals, which could be due to Se losses through the perspiration. This fact agrees with some authors (30) who have indicated that Se losses via perspiration may contribute to the decrease of urinary Se excretion in chemical factory workers. When the urinary Se excretion is related to the weight of the individuals, the mean values observed were independent of physical exercise.

A correlational study was carried out among the studied variables for all the population and considering the different groups as a function of sex, age, weight and height and the studied habits. Daily urinary Se excretion was slightly correlated with daily creatinine excretion, which has been observed by other authors (11). A significant correlation was observed between urinary concentrations of Se $(\mu \mathrm{g} / \mathrm{l})$ and of creatinine $(\mathrm{mg} / \mathrm{l})$ :

$$
\begin{aligned}
& \log (\mathrm{Se}, \mu \mathrm{g} / \mathrm{l}) \\
& =0.290 \log (\text { creatinine } \mathrm{mg} / \mathrm{l})+0.485 \\
& \quad(\mathrm{r}=0.365, \mathrm{P}=0.0009)
\end{aligned}
$$

The fact that Se excretion is directly correlated with the creatinine excretion confirms that the muscle mass influences the Se excretion in urine (11). When the urinary Se excretion $(\mu \mathrm{g} / \mathrm{d})$ was correlated with the unit of urinary Se concentration ( $\mu \mathrm{g} / \mathrm{g}$ of creatinine), a more significant correlation was obtained than with the other unit of Se concentration $(\mu \mathrm{g} / \mathrm{l})$. These results seem to confirm that the utilization of the unit $\mathrm{Se}, \mu \mathrm{g} / \mathrm{g}$ of creatinine is a more adequate indicator of the urinary Se excretion than the unit of concentration $\mu \mathrm{g} / 1(11,31-32)$. Daily total volume of urine was positively correlated with the daily urinary $\mathrm{Se}$ and of creatinine excretions. However, daily total volume of urine correlated negatively with the urinary Se concentrations. Also, significant correlations were observed between both urinary Se excretions studied in this paper and the age, weight, and height. These correlations were positive and negative when the used Se excretions were $\mu \mathrm{g} / \mathrm{d}$ and $\mu \mathrm{g} / \mathrm{d} \cdot \mathrm{kg}$, respectively.

\section{Concluding remarks}

1. Urinary Se concentrations and excretions of Canarian people are similar to those found in most European regions, which are closer to the urinary Se levels that would be expected in non-seleniferous areas or normal reference values.

2. Females excreted daily in urine significantly $(P=0.005)$ higher amounts of Se per $\mathrm{kg}$ of body weight than males. Thus, males tend to retain Se more efficiently or excrete more $\mathrm{Se}$ in other ways, than females.

3. Children $(<10$ years old) presented significantly lower levels of daily $\mathrm{Se}$ excretion $(\mathrm{P}=0.008)$ and higher levels of daily Se excretion per $\mathrm{kg}(\mathrm{P}=0.000)$, than individuals with ages $>10$ years old.

4. Se excretion in urine $(\mu \mathrm{g} / \mathrm{d})$ significantly $(P<0.040)$ increased with the weight and height of the individuals.

5. There is no evidence of any significant differences in urinary Se concentrations and excretions considering some eating habits such as: consumption of rich protein food or rich fibre food, and consumption of alcohol or coffee. A tobacco smoking habit has not significantly influenced the urinary Se status, either.

6. Significant $(P=0.038)$ depletion of the urinary daily Se excretion was observed with the increase of physical exercise practised by the individuals, which could be due to Se losses through perspiration.

7. Correlation studies have confirmed the relation between Se and of creatinine present in urine.

8. The use of the unit of concentration (Se, $\mu \mathrm{g} / \mathrm{g}$ of creatinine) is a more adequate indicator of the urinary Se excretion than the unit of concentration of $\mu \mathrm{g} / \mathrm{l}$. However, the Se excretion per $24 \mathrm{~h}$ best describes the losses of selenium via urine.

\section{Acknowledgement}

We gratefully acknowledge the help of Patrick Dennis in improving the English in this article. E. Ma Rodriguez Rodriguez wants to acknowledge to the Gobierno de Canarias by a grant for carrying out the experimental work of her thesis.

\section{References}

1. Shamberger SJ. Selenium metabolism and function. Clin Physiol Biochem 1986; 4:42-9.

2. Arthur JR, Geoffrey GJ. Roles in selenium in type I iodothyronine-5'-deiodinase and in thyroid hormone and iodine metabolism. In: Purk RF, editor. Selenium biology and human health. New York: Springer, 1994:93-115.

3. Taurog A, Dorris ML, Guziec LJ, Guziec FS. The selenium analog of methimazole - measurement of its inhibitory effect

on type I 5'-deiodinase and of its antithyroid activity. Biochem Pharmacol 1994; 48:1447-55.

4. Zwahlen BA, Cammack PM, Christensen MJ. Thyroid hormone metabolism in relation to dietary selenium intake in Guinea pigs. FASEB J 1994; 7:A289.

5. Koehrle J. Thyroid hormone deiodination in target tissues a regulatory role for the trace element selenium? Exp Clin Endocrinol 1994; 103:63-89. .; 
6. Sanz M, Diaz C. Urinary selenium concentrations [Review]. Clin Chem 1993; 39:2040-52.

7. Iyengar V, Woittiez J. Trace elements in human clinical specimens: evaluation of literature data to identify reference values. Clin Chem 1988; 34:474-81.

8. Rodriguez EM, Sanz M, Diaz C. Critical study of fluorimetric determination of selenium in urine. Talanta 1994; 41:2025-31.

9. Bartels $\mathrm{H}$, Boehmer $\mathrm{M}$. Microdetermination of creatinine. Clin Chim Acta 1971; 32:81-5.

10. Watkinson JH. Fluorimetric determination of selenium in biological material with 2,3-diaminonaphthalene. Anal Chem 1966; 38:92-7.

11. Oster O, Prellwitz W. The renal excretion of selenium. Biol Trace Elem Res 1990; 24:119-46.

12. Geahchan A, Chambon P. Fluorometry of selenium in urine. Clin Chem 1980; 26:1272-4.

13. Wasowicz W, Zachara BA. Selenium concentrations in the blood and urine of a healthy Polish sub-population. $J$ Clin Chem Clin Biochem 1987; 25:409-12.

14. Mikac-Devic M, Vukelic N, Kljaic K. Urine selenium level in healthy adult population. Biol Trace Elem Res 1993; 36:283-90.

15. Hasunuma R, Tsuda M, Ogawa T, Kawanishi Y. Urinary selenium levels in Japanese males and females. Bull Environ Contam Toxicol 1990; 44:501-7.

16. Bratakos MS, Kanaki HC, Vasiliou-Waite A, Ioannou PV. The nutritional selenium status of healthy Greeks. Sci Total Environ $91: 161-76$.

17. Alexander J, Thomassen $\mathrm{Y}$, Aaseth J. Increased urinary excretion of selenium among workers exposed to elemental mercury vapor. J Appl Toxicol 1993; 3:143-5.

18. Robberecht HJ, Deelstra HA. Selenium in human urine. Determination, speciation and concentration levels. Talanta 1984; 31:497-508.

19. Suzuki T, Hongo T, Ohba T, Kobayashi K, Imai H, Ishida $H$, Suzuki $H$. The relation of dietary selenium to erythrocyte and plasma selenium concentrations in Japanese college women. Nutr Res 1989; 9:839-48.

20. Yoshida $M$, Sunaga $M$, Hara I. Selenium status in workers handling aromatic nitro-amino compounds in a chemical factory. J Toxicol Environ Health 1990; 31:1-10.

21. Palmer IS, Olson OE, Ketterling L. Selenium intake and urinary excretion in persons living near a high selenium area. $J$ Am Diet Assoc 1983; 82:511-5.
22. Dutta SK, Miller P, Greenberg L, Levander OA. Evidence for selenium depletion in alcoholic subjects admitted for detoxification. Am J Clin Nutr 1982; 35:845.

23. Välimäki MJ, Harju KJ, Ylikahri RH. Decreased serum selenium in alcoholics - a consequence of liver dysfunction. Clin Chim Acta 1983; 130:291-6.

24. Tanner AR, Bertock I, Hinks L, Lloyd B, Turner NR, Wright $R$. Depressed selenium and vitamin $E$ levels in an alcoholic populations. Possible relationship to hepatic injury through increased lipid peroxidation. Dig Dis Sci 1986; 31:1307-12.

25. Bjorneboe G-EA, Johnson J, Bjorneboe A, Bache-Wiig JE, Moerland J, Drevon CA. Diminished serum concentrations of vitamin $\mathrm{E}$ in alcoholics. Ann Nutr Metab 1988; 32:56-1.

26. Snook JT. Effect of ethanol use and other lifestyle variables on measures of selenium status. Alcohol 1991; 8:13-6.

27. Ellis N, Lloyd B, Lloyd RS, Clayton BE. Selenium and vitamin $\mathrm{E}$ in relation to risk factors for coronary heart disease. $\mathrm{J}$ Clin Pathol 1984; 37:200-6.

28. Sesana G, Baj A, Toffoletto F, Sega R, Ghezzi L. Plasma selenium levels of the general population of an area in northern Italy. Sci Total Environ 1992; 120:97-102.

29. Cannon DC. Pruebas de funcionamiento renal. In: Henry RJ, Cannon DC, Winkelman JW, editors. Química Clínica. Barcelona: JIMS, 1980:1547-65.

30. Zachara BA, Wasowicz W, Sklodowska M, Gromadzinska A. Selenium status, lipid peroxides concentration, and glutathione peroxidase activity in the blood of power station and rubber factory workers. Arch Environ Health 1987; 42:223-9.

31. Hojo Y. Evaluation of the expression of urinary selenium level as nanograms of Se per milligram of creatinine and the use of single-void urine as a sample for urinary selenium determination. Bull Environ Contam Toxicol 1981; 27:213-20.

32. Hojo Y. Single-void urine selenium level expressed in terms of creatinine content as an effective and convenient indicator of human selenium status. Bull Environ Contam Toxicol 1982; 29:37-42.

Dr. Carlos Díaz Romero

Dept. of Analytical Chemistry

Food Science \& Technology

University of La Laguna

E-38071 La Laguna

Spain 
